\title{
Biodegradation of biphenyl compounds by soil microbiomes
}

\section{Conceptual}

Biphenyls are basically organic compounds which are produced at industrial level as by products. Biphenyls are produced by dealkylation of the toluene. Polychlorinated biphenyl (PCBs) is derivative of biphenyl and used in different applications such as the manufacture of oil condensers, plasticizers, dielectrics, and hydraulic fluids. Along with useful products, there are number of organic pollutants productions which are toxic in nature. Polychlorinated biphenyls are not readily broken down in the environment. PCBs are remaining there for longer periods of the time cycling between air, water and soil. The polychlorinated biphenyls are known to inflict serious impacts on the reproductive, immune, nervous, endocrine systems in animals. The polychlorinated biphenyl are also causing cancer. $^{1,2}$ The microbiomes are ubiquitous in nature and have been reported from extreme environments and well as plant associated. Among microbes from diverse habitats the soil microbiomes play an important role in degradation of PCBs. A number of soil microbiomes have PCBs degrading capability have been isolated and characterized belonging to different genera Williamsia, Trametes, Talaromyces, Stenotrophomonas, Sphingomonas, Sphingobium, Shigella, Rhodococcus, Pseudomonas, Paenibacillus, Ochrobactrum, Janthinobacterium, Janibacter, Bacillus, Aspergillus, Arthrobacter and Achromobacter. On review of different research it can be concluded that the soil microbiomes degradating polychlorinated biphenyl belongs to phylum Proteobacteria, Firmicutes, Basidiomycota, Bacteroidetes, Ascomycota, Actinobacteria and Euryarchaeota.

The soil microbiomes play a vital role in the degradation of the biphenyls and a basic pathway has been reported in different studies used by bacteria to degrade the biphenyls. ${ }^{4-19}$ The soil microbiomes produced number of numbers of extracellular hydrolytic enzymes which are involved in the degradation of the biphenyls. Bioremediation by soil microbiomes have been investigated extensively during the last few decades. The microbes having capability to degradation is an alternative and less expensive strategy. ${ }^{19,20}$ The culturable useful industrially and agriculturally important microbes are ubiquitous in nature and have been reported from diverse habitats including low temperature, ${ }^{21-23}$ high temperature, ${ }^{24,25}$ hypersaline environments, ${ }^{26,27}$ saline lake, ${ }^{28-30}$ sub-glacial lake, ${ }^{31,32}$ and Drought environments. ${ }^{33-36}$

There are number of microbes which have been reported to possess the ability to degrade biphenyls including Sphingomonas sp., Ralstonia sp., Pseudomonas sp., Corynebacterium sp., Comamonas sp., Burkholderia sp., Bacillus sp., Alcaligenes sp., Acinetobacter sp., Achromobacter sp. ${ }^{37}$ Cupriavidus pauculus, ${ }^{38}$ Hydrogenophaga taeniospiralis, ${ }^{39}$ Paenibacillus sp., ${ }^{40}$ Pseudomonas putida, ${ }^{41}$ Rhodococcus erythropolis TA421, ${ }^{42}$ Rhodococcus globerulus P6, ${ }^{43}$ Rhodococcus jostii, ${ }^{44}$ Rhodococcus rhodochrous K37, ${ }^{45}$ Rhodococcus sp. M5 ${ }^{46}$ Rhodococcus sp. HA $99^{47}$ and Enterobacter sp. ${ }^{48}$ The potential and efficient soil microbiomes has been isolated and characterized to degradates different toxic compounds from diverse sources.

The abundance and distribution of biphenyl compounds degrading microbes have been reported from diverse environment

\author{
Volume 3 Issue 2 - 2019
}

\author{
Neelam Yadav,' Ajar Nath Yadav ${ }^{2}$ \\ 'Gopi Nath PG College, India \\ ${ }^{2}$ Eternal University, India
}

Correspondence: Neelam Yadav, Gopi Nath P.G. College, Deoli-Salamatpur, Ghazipur, Uttar Pradesh, India,

Email neelamanyadav@gmail.com

Received: January II, 2019 | Published: March 15, 2019

niches/habitats such as Rhodococcus erythropolis TA421 from termite ecosystem; ${ }^{42}$ Achromobacter piechaudii BioC1, ${ }^{49}$ Bacillus thuringiensis Bt-NGRA, ${ }^{50}$ Comamonas testosteroni TK102, ${ }^{51}$ Cupriavidus pauculus KF709, ${ }^{38}$ Hydrogenophaga sp. IA3-A, ${ }^{52}$

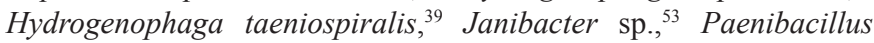
sp. KBC101, ${ }^{40}$ Pseudomonas aeruginosa KF702, ${ }^{54}$ Pseudomonas alcaliphila JAB $1,{ }^{55}$ Pseudomonas plecoglossicida $6.1,{ }^{49}$ Pseudomonas putida KF715, ${ }^{41}$ Pseudomonas stutzeri, ${ }^{56}$ Pseudomonas toyotomiensis KF710, ${ }^{57}$ Rhodococcus pyridinivorans, ${ }^{58}$ Rhodococcus ruber $\mathrm{P} 25,{ }^{59}$ Rhodococcus $s p . \mathrm{WB} 1^{60}$ and Sphingobium fuliginis $\mathrm{HC}^{61}$ from rhizospheric and soil ecosystems; Luteibacter sp., Rhodococcus sp., ${ }^{62}$ Talaromyces helices ${ }^{63}$ and Williamsia sp. $^{62}$ from contaminated soil; Chitinophaga sp., Janthinobacterium sp., Pseudomonas sp., Shigella sp. and Subtercola sp. $^{64}$ from Cryoconite; Cupriavidus sp. SK-4, ${ }^{65}$ Aquamicrobium sp. strain SK-2 ${ }^{66}$ and Cupriavidus sp. SK- $3{ }^{67}$ from sewage sludge; Doratomyces nanus, Doratomyces purpureofuscus, Doratomyces verrucisporus, Myceliophthora thermophila, Phoma eupyrena and Thermoascus crustaceus $^{68}$ from Industrial sites and Mesorhizobium sp. ZY ${ }^{69}$ from legume Astragalus.

Biodegradation is a chemical process involving breakdown of materials by bacteria, fungi, or other biological means. Biological degradation of polychlorinated biphenyls is a striking clean-up approach as it is environmentally friendly and worthwhile. ${ }^{70}$ It has been stated that several microorganisms such as bacteria, fungi and yeasts can metabolize Polychlorinated biphenyls (PCBs). ${ }^{19,68,71}$ There have been reports on microbes degrading biphenyl and showing chemotactic response towards 4-chlorobenzoate (4-CBA), benzoate, biphenyl, and polychlorinated biphenyl. ${ }^{72-74}$ Fungi are known to utilize a varied range of organic compounds for nutrition and energy generation. In the past few years, use of fungi to clean up the environmental pollutants has gained tremendous importance. ${ }^{75,76}$ Numerous authors have also reported the ability of $P$. chrysosporium to be ubiquitous PAH degraders with the extracellular ligninolytic enzyme system, which includes lignin peroxidase (LiP), manganese peroxidase (MnP), versatile peroxidase (VP), and laccase. ${ }^{77-80}$ Phanerochaete chrysosporium reported to degrade benzo(a)pyrene one of the polycyclic aromatic hydrocarbons (PAHs) significantly. ${ }^{81}$

\section{Conclusion}

Polychlorinated biphenyls (PCBs) are among the most widely used industrial materials and possess a number of applications but 
due to complexity in their structure they are highly recalcitrant and further causes a lot to environmental as well as the health issues. There are number of microbes which have been reported to degrade PCBs and even various studies have taken into consideration the genetic organization of the catabolic genes for the biodegradation of the biphenyls and further, various have studied about the degradation pathways of various microbes. Complex congener mixtures which cannot sometimes be degraded easily by single microbe, consortium can prove versatile in this regard. Thus, microbes bringing about the degradation should be more explored and they will surely prove as novel tool to remove these complex compounds from the environment.

\section{Acknowledgments}

None.

\section{Conflicts of interest}

The author declares there is no conflicts of interest.

\section{References}

1 Aoki Y. Polychlorinated biphenyls, polychloronated dibenzo-p-dioxins, and polychlorinated dibenzofurans as endocrine disrupters what we have learned from Yusho disease. Environ Res. 2001;86(1):2-11.

2 Faroon O, Jones D, De Rosa C. Effects of polychlorinated biphenyls on the nervous system. Toxicol Ind Health. 2000;16(7-8):305-333.

3 Kour D, Rana KL, Kumar R, et al. New and Future Developments in Microbial Biotechnology and Bioengineering. In: Harikesh Bahadur Singh, Vijai Kumar Gupta, et al, editors. Elsevier, 2019.

4 Abramowicz DA. Aerobic and anaerobic biodegradation of PCBs: a review. Critical Reviews in Biotechnology. 1990;10(3):241-251.

5 Furukawa K, Fujihara H. Microbial degradation of polychlorinated biphenyls: biochemical and molecular features. $J$ Biosci Bioeng. 2008;105(5):433-449.

6 Furukawa K. Molecular genetics and evolutionary relationship of PCBdegrading bacteria. Biodegradation. 1994;5(3-4):289-300.

7 Seeger M, Timmis KN, Hofer B. Conversion of chlorobiphenyls into phenylhexadienoates and benzoates by the enzymes of the upper pathway for polychlorobiphenyl degradation encoded by the bph locus of Pseudomonas sp. strain LB400. Appl Environ Microbiol. 1995;61(7):2654-2658.

8 Unterman R. Cambridge University Press: New York, 1996.

9 Shukla L, Suman A, Yadav AN, et al. Syntrophic microbial system for ex-situ degradation of paddy straw at low temperature under controlled and natural environment. J App Biol Biotech. 2016;4(2):30-37.

10 Bergeron J, Ahmad D, Barriault D, et al. Identification and mapping of the gene translation products involved in the first steps of the Comamonas testosteroni B-356 biphenyl/chlorobiphenyl biodegradation pathway. Can J Microbiol. 1994;40(9):743-753.

11 Furukawa K, Miyazaki T. Cloning of a gene cluster encoding biphenyl and chlorobiphenyl degradation in Pseudomonas pseudoalcaligenes. $J$ Bacteriol. 1986;166(2):392-398.

12 Hayase N, Taira K,Furukawa K. Pseudomonas putida KF715 bphABCD operon encoding biphenyl and polychlorinated biphenyl degradation: cloning, analysis, and expression in soil bacteria. $J$ Bacteriol. 1990;172(2):1160-1164.

13 Kimbara K, Hashimoto T, Fukuda M, et al. Cloning and sequencing of two tandem genes involved in degradation of 2, 3-dihydroxybiphenyl to benzoic acid in the polychlorinated biphenyl-degrading soil bacterium Pseudomonas sp. strain KKS102. J Bacteriol. 1989;171(5):2740-2747.
14 Mondello FJ. Cloning and expression in Escherichia coli of Pseudomonas strain LB400 genes encoding polychlorinated biphenyl degradation. $J$ bacteriol. 1989;171(3):1725-1732.

15 Hooper S, Dockendorff T, Sayler G. Characteristics and restriction analysis of the 4-chlorobiphenyl catabolic plasmid, pSS50. Appl Environ Microbiol. 1989;55(5):1286-1288.

16 Yamada A, Kishi H, Sugiyama K, et al. Two nearly identical aromatic compound hydrolase genes in a strong polychlorinated biphenyl degrader, Rhodococcus sp. strain RHA1. Appl Environ Microbiol. 1998;64(6):2006-2012.

17 Lloyd Jones G, de Jong C, Ogden RC, et al. Recombination of the bph (biphenyl) catabolic genes from plasmid pWW100 and their deletion during growth on benzoate. Appl Environ Microbiol. 199460(2):691696.

18 Springael D, Kreps S, Mergeay M. Identification of a catabolic transposon, Tn4371, carrying biphenyl and 4-chlorobiphenyl degradation genes in Alcaligenes eutrophus A5. J Bacteriol. 1993;175(6):1674-1781.

19 Chang YC, Takada K, Choi D, et al. Isolation of biphenyl and polychlorinated biphenyl-degrading bacteria and their degradation pathway. Appl Biochem Biotechnol. 2013;170(2):381-398.

20 Furukawa K. Microbial metabolism of polychlorinated biphenyls. Studies on the reletive dagradability of polychlorinated biphenyl components by Alcalogenes sp. J Agric Food Chem. 1976;24(2):251-256.

21 Yadav AN. Bacterial diversity of cold deserts and mining of genes for low temperature tolerance Ph.D. thesis, 2015.

22 Yadav AN, Sachan SG, Verma P, et al. Prospecting cold deserts of north western Himalayas for microbial diversity and plant growth promoting attributes. J Biosci Bioeng. 2015;119(6):683-693.

23 Yadav AN, Sachan SG, Verma P, et al. Culturable diversity and functional annotation of psychrotrophic bacteria from cold desert of Leh Ladakh (India). World J Microbiol Biotechnol. 2015;31(1):95-108.

24 Sahay H, Yadav AN, Singh AK, et al. Hot springs of Indian Himalayas: Potential sources of microbial diversity and thermostable hydrolytic enzymes. 3 Biotech. 2017;7(2):1-11.

25 Singh RN, Gaba S, Yadav AN, et al. First, High quality draft genome sequence of a plant growth promoting and Cold Active Enzymes producing psychrotrophic Arthrobacter agilis strain L77. Stand Genomic Sci. 2016;11(1):54

26 Yadav AN, Sharma D, Gulati S, et al. Haloarchaea endowed with phosphorus solubilization attribute implicated in phosphorus cycle. Sci Rep. 2015;5.

27 Gaba S, Singh RN, Abrol S, et al. Draft genome sequence of Halolamina pelagica CDK2 isolated from natural salterns from Rann of Kutch, Gujarat, India. Genome Announc. 2017;5(6):1-2.

28 Saxena AK, Yadav AN, Rajawat M, et al. Microbial diversity of extreme regions: An unseen heritage and wealth. Indian J Plant Genet Resour. 2016;29(3):246-248.

29 Yadav AN, Kumar R, Kumar S, et al. Beneficial microbiomes: Biodiversity and potential biotechnological applications for sustainable agriculture and human health. Journal of Applied Biology \& Biotechnology. 2017;5(6):45-57.

30 Yadav AN, Saxena AK. Biodiversity and biotechnological applications of halophilic microbes for sustainable agriculture. Journal of Applied Biology \& Biotechnology. 2018;6(1):48-55.

31 Yadav AN, Sachan SG, Verma P, et al. Cold active hydrolytic enzymes production by psychrotrophic Bacilli isolated from three sub-glacial lakes of NW Indian Himalayas. J Basic Microbiol. 2016;56(3):294-307. 
32 Yadav AN, Verma P, Sachan SG, et al. Biodiversity and biotechnological applications of psychrotrophic microbes isolated from Indian Himalayan regions. EC Microbiol. 2017;ECO.01:48-54.

33 Yadav AN, Verma P, Kumar M, et al. Diversity and phylogenetic profiling of niche-specific Bacilli from extreme environments of India. Ann Microbiol. 2015;65(2):611-629.

34 Verma P, Yadav AN, Kazy SK, et al. Evaluating the diversity and phylogeny of plant growth promoting bacteria associated with whea (Triticum aestivum) growing in central zone of India. Int $J$ Curr Microbiol Appl Sci. 2014;3(5):432-447.

35 Verma P, Yadav AN, Khannam KS, et al. Molecular diversity and multifarious plant growth promoting attributes of Bacilli associated with wheat (Triticum aestivum L.) rhizosphere from six diverse agroecological zones of India. J Basic Microbiol. 2016;56(1):44-58.

36 Verma P, Yadav AN, Khannam KS, et al. Appraisal of diversity and functional attributes of thermotolerant wheat associated bacteria from the peninsular zone of India. Saudi J Biol Sci. 2016.

37 Furukawa K. Biochemical and genetic bases of microbial degradation of polychlorinated biphenyls (PCBs). J Gen Appl Microbiol 2000;46(6):283-296.

38 Watanabe T, Yamazoe A, Hosoyama A, et al. Draft genome sequence of Cupriavidus pauculus strain KF709, a biphenyl-utilizing bacterium isolated from biphenyl-contaminated soil. Genome announc. 2015;3(2):e00222-00215.

39 Lambo AJ, Patel TR. Isolation and characterization of a biphenyl-utilizing psychrotrophic bacterium, Hydrogenophaga taeniospiralis IA3-A, that cometabolize dichlorobiphenyls and polychlorinated biphenyl congeners in Aroclor 1221. J Basic Microbiol. 2006;46(2):94-107.

40 Sakai M, Ezaki S, Suzuki N, et al. Isolation and characterization of a novel polychlorinated biphenyl-degrading bacterium, Paenibacillus sp. KBC101. Appl Microbiol Biotechnol. 2005;68(1):111-116.

41 Suenaga H, Yamazoe A, Hosoyama A, et al. Complete genome sequence of the polychlorinated biphenyl-degrading bacterium Pseudomonas putida KF715 (NBRC 110667) isolated from biphenyl-contaminated soil. Genome announc. 2017;5(7):e01624-01616.

42 Chung SY, Maeda M, Song E, et al. A Gram positive polychlorinated biphenyl degrading bacterium, Rhodococcus erythropolis strain TA421, isolated from a termite ecosystem. Bioscience, biotechnology, and biochemistry. 1994;58(11):2111-2113.

43 McKay DB, Prucha M, Reineke W, et al. Substrate specificity and expression of three 2, 3-dihydroxybiphenyl 1, 2-dioxygenases from Rhodococcus globerulus strain P6. J Bacteriol. 2003;185(9):2944-2951.

44 Atago Y, Shimodaira J, Araki N, et al. Identification of novel extracellular protein for PCB/biphenyl metabolism in Rhodococcus jostii RHA1. Biosci, biotechnol, and biochem. 2016;80(5):1012-1019.

45 Taguchi K, Motoyama M, Kudo T. Multiplicity of 2, 3-dihydroxybipheny dioxygenase genes in the Gram-positive polychlorinated biphenyl degrading bacterium Rhodococcus rhodochrous K37. Biosci, biotechnol, and biochem. 2004;68(4):787-795.

46 Labbe D, Garnon J, Lau P. Characterization of the genes encoding a receptor-like histidine kinase and a cognate response regulator from a biphenyl/polychlorobiphenyl-degrading bacterium, Rhodococcus $\mathrm{sp}$ strain M5. J Bacteriol. 1997;179(8):2772-2776.

47 Taguchi K, Motoyama M, Iida T, et al. Polychlorinated biphenyl/ biphenyl degrading gene clusters in Rhodococcus sp. K37, HA99, and TA431 are different from well-known bph gene clusters of Rhodococci. Biosci, biotechnol, and biochem. 2007;71(5):1136-1144.
48 Cai M, Song G, Li Y, et al. A novel Aroclor 1242-degrading culturable endophytic bacterium isolated from tissue culture seedlings of Salix matsudana f. pendula Schneid. Phytochemistry Letters. 2018;23:66-72.

49 Blanco Moreno R, Saez LP, Luque Almagro VM, et al. Isolation of bacterial strains able to degrade biphenyl, diphenyl ether and the heat transfer fluid used in thermo-solar plants. N Biotechnol. 2017;35:35-41.

50 Tenorio Sánchez S, Rojas Avelizapa N, Ibarra J, et al. Characterization of a Bacillus thuringiensis strain isolated from a highly polychlorinated biphenyls contaminated soil. Tecnologa. 2010;3:52-63.

51 Fukuda K, Hosoyama A, Tsuchikane K, et al. Complete genome sequence of polychlorinated biphenyl degrader Comamonas testosteroni TK102 (NBRC 109938). Genome announc. 2014;2(5):e00865-00814.

52 Lambo AJ, Patel TR. Cometabolic degradation of polychlorinated biphenyls at low temperature by psychrotolerant bacterium Hydrogenophaga sp. IA3-A. Curr Microbiol. 2006;53(1):48-52.

53 Sierra I, Valera JL, Marina ML, et al. Study of the biodegradation process of polychlorinated biphenyls in liquid medium and soil by a new isolated aerobic bacterium (Janibacter sp.). Chemosphere. 2003;53(6):609-618.

54 Fujihara H, Yamazoe A, Hosoyama A, et al. Draft genome sequence of Pseudomonas aeruginosa KF702 (NBRC 110665), a polychlorinated biphenyl-degrading bacterium isolated from biphenyl-contaminated soil. Genome announc. 2015;3(3):e0517-00515.

55 Ridl J, Suman J, Fraraccio S, et al. Complete genome sequence of Pseudomonas alcaliphila JAB1 (= DSM 26533), a versatile degrader of organic pollutants. Stand Genomic sci. 2018;13(1):3.

56 Dercová K, Baláž Š, Haluška L, et al. Degradation of PCB by bacteria isolated from long-time contaminated soil. International journal of environmental analytical chemistry. 1995;58(1-4):337-348.

57 Watanabe T, Yamazoe A, Hosoyama A, et al. Draft genome sequence of Pseudomonas toyotomiensis KF710, a polychlorinated biphenyl degrading bacterium isolated from biphenyl contaminated soil. Genome announc. 2015;3(2):e00223-00215.

58 Wang $\mathrm{H}, \mathrm{Hu} \mathrm{J}, \mathrm{Xu} \mathrm{K}$, et al. Biodegradation and chemotaxis of polychlorinated biphenyls, biphenyls, and their metabolites by Rhodococcus spp. Biodegradation. 2018;29(1):1-10.

59 Shumkova ES, Olsson BE, Kudryavtseva AV, et al. Draft genome sequence of Rhodococcus ruber strain P25, an active polychlorinated biphenyl degrader. Genome announc. 2015;3(5):e00990-00915.

$60 \mathrm{Xu} \mathrm{Y,} \mathrm{Yu} \mathrm{M,} \mathrm{Shen} \mathrm{A.} \mathrm{Complete} \mathrm{Genome} \mathrm{Sequence} \mathrm{of} \mathrm{the} \mathrm{Polychlorinated}$ Biphenyl Degrader Rhodococcus sp. WB1. Genome announc. 2016;4(5):e00996-00916.

$61 \mathrm{Hu}$ J, Qian M, Zhang Q, et al. Sphingobium fuliginis HC3: a novel and robust isolated biphenyl-and polychlorinated biphenyls degrading bacterium without dead end intermediates accumulation. PloS one. 2015;10(4):e0122740.

62 Leigh MB, Prouzová P, Macková M, et al. Polychlorinated biphenyl (PCB)-degrading bacteria associated with trees in a PCB-contaminated site. Appl Environ Microbiol. 2006;72(4):2331-2342.

63 Romero MC, Hammer E, Hanschke R, et al. Biotransformation of biphenyl by the filamentous fungus Talaromyces helicus. World $J$ Microbiol Biotechnol. 2005;21(2):101-106.

64 Weiland Bräuer N, Fischer MA, Schramm KW, et al. Polychlorinated Biphenyl (PCB) Degrading Potential of Microbes Present in a Cryoconite of Jamtalferner Glacier. Front Microbiol. 2017;8:1105.

65 Vilo C, Benedik MJ, Ilori M, et al. Draft genome sequence of Cupriavidus sp. strain SK-4, a di-ortho substituted biphenyl-utilizing bacterium isolated from polychlorinated biphenyl-contaminated sludge. Genome announc. 2014;2(3):e00474-00414. 
66 Chang YC, Sawada K, Kim ES, et al. Whole genome sequence of Aquamicrobium sp. strain SK-2, a polychlorinated biphenylutilizing bacterium isolated from sewage sludge. Genome announc. 2015;3(3):e00439-00415.

67 Kim S, Picardal FW. A novel bacterium that utilizes monochlorobiphenyls and 4-chlorobenzoate as growth substrates. FEMS Microbiology Letters. 2000;185(2):225-229.

68 Mouhamadou B, Faure M, Sage L, et al. Potential of autochthonous fungal strains isolated from contaminated soils for degradation of polychlorinated biphenyls. Fungal Biol. 2013;117(4):268-274.

69 Teng Y, Li X, Chen T, et al. Isolation of the PCB degrading bacteria Mesorhizobium sp. ZY1 and its combined remediation with Astragalus sinicus L. for contaminated soil. Int J Phytoremediation. 2016;18(2):141149 .

70 Ohtsubo Y, Kudo T, Tsuda M, et al. Strategies for bioremediation of polychlorinated biphenyls. Appl Microbiol Biotechnol. 2004;65(3):250 258 .

71 Sietmann R, Gesell M, Hammer E, et al. Oxidative ring cleavage of low chlorinated biphenyl derivatives by fungi leads to the formation of chlorinated lactone derivatives. Chemosphere. 2006;64(4):672-685.

72 Harwood CS. A methyl-accepting protein is involved in benzoate taxis in Pseudomonas putida. J Bacteriol. 1989;171(9):4603-4608.

73 Wu G, Feng Y, Boyd S. Characterization of bacteria capable of degrading soil-sorbed biphenyl. Bull Environ Contam Toxicol. 2003;71(4):768-775.

74 Gordillo F, Chávez FP, Jerez CA. Motility and chemotaxis of Pseudomonas sp. B4 towards polychlorobiphenyls and chlorobenzoates. FEMS microbiol ecol. 2007;60(2):322-328.
75 Beaudette LA, Davies S, Fedorak PM, et al. Comparison of gas chromatography and mineralization experiments for measuring loss of selected polychlorinated biphenyl congeners in cultures of white rot fungi. Appl Environ Microbiol. 1998;64(6):2020-2025.

76 Yadav J, Quensen JF, Tiedje JM, et al. Degradation of polychlorinated biphenyl mixtures (Aroclors 1242, 1254, and 1260) by the white rot fungus Phanerochaete chrysosporium as evidenced by congener specific analysis. Appl Environ Microbiol. 1995;61(7):2560-2565.

77 Sack U, Hofrichter M, Fritsche W. Degradation of polycyclic aromatic hydrocarbons by manganese peroxidase of Nematoloma frowardii. FEMS Microbiol Lett. 1997;152(2):227-234.

78 Kim MS, Huh EJ, Kim HK, et al. Degradation of polycyclic aromatic hydrocarbons by selected white rot fungi and the influence of lignin peroxidase. Journal of microbiology and biotechnology. 1998;8(2):129_ 133.

79 Camacho Morales RL, Gerardo Gerardo J, Guillen KN, et al. Ligninolytic enzyme production by white rot fungi during paraquat (herbicide) degradation. Rev Argent Microbiol. 2017;49(2):189-196.

80 Qin X, Sun X, Huang H, et al. Oxidation of a non-phenolic lignin model compound by two Irpex lacteus manganese peroxidases: evidence for implication of carboxylate and radicals. Biotechnology for Biofuels. 2017;10(1):103.

81 Chigu NL, Ichinose H. Cellular Uptake and Metabolism of High Molecular Weight Polycyclic Aromatic Hydrocarbons by the White-rot Fungus Phanerochaete chrysosporium. Resources and Environment. 2017;7(5):138-144. 